\title{
The Politics of Imagery: Understanding the Historical Genesis of Sinophobia in Pacific Geopolitics
}

\section{Steven Ratuva ${ }^{1}$}

Received: 11 May 2021 / Accepted: 24 September 2021 / Published online: 25 October 2021

(C) The Author(s), under exclusive licence to Springer Nature B.V. 2021

\begin{abstract}
The weaponization of racialized imagery has been a common feature of geopolitical contestation in contemporary history. The paper critically examines the historical genesis of Sinophobic narratives, which have been common features of the big power geopolitical contestation in the Pacific. The globalization of capitalism in the nineteenth century and the West's attempts to penetrate the Chinese market and exploitation of its resources led to tension, skirmishes and wars. The myth of racial European superiority and corresponding inferiority of the Chinese was weaponized as an ideological justification for colonial domination, exploitation of cheap labour and appropriation of China's resources and wealth. In recent years, the Sinophobic paranoia has been exacerbated by China's Belt and Road initiative, a strategy at global economic and technological supremacy to counter the West's dominance. This competition for global hegemony is played out in various parts of the world and the Pacific included. The paper critically discusses various historical factors associated with Sinophobia in the context of the USA, France and Australia and how these have influenced these countries' contemporary approaches to Chinese expansionism.
\end{abstract}

Keywords Sinophobia $\cdot$ Racialization $\cdot$ Pacific $\cdot$ Geopolitics $\cdot$ China $\cdot$ Colonialism

\section{Introduction}

In his article, 'Unravelling the concept of unconscious bias', Bourne states that 'The word shifts blame, the word redefines, the word predicates' [1]. The power of words to frame, create imageries and racial stereotypes has normative characteristics (positive or negative), has consequences on others and it often works both ways [2]. Stereotype is not just based on the construction of imageries, or based on prejudices; beyond that, it can also be a powerful subconscious force in framing political, strategic and economic policies in times of conflict [3]. We have seen how ideological

Steven Ratuva

Steven.ratuva@canterbury.ac.nz

1 University of Canterbury, Christchurch, New Zealand 
representation of each other helped fuelled the Cold War contestation between the USA and the Soviet Union [4] and the anti-Islamic fervour during the so-called war on terror [5].

For years, indeed since the period of the Enlightenment (seventeenth to eighteenth century), the European perception of other cultures had been framed by a grand narrative of human progression where the West was seen as representing the apex of human evolution. This belief was central to the social Darwinian theory in the social sciences, which provided the ideological justification for colonialism and global empire building [6]. The idea of racial and cultural differences as a basic tenet of social discourse has prevailed over the years as a way of framing social change and human conflict. A prominent case of this strand of view is Huntington's notion of 'clash of civilizations' and his division of the world into separate and competing civilizations [7]. Huntington argues that Western civilization is naturally dominant and remains distinctive from other cultures:

European communities...will share cultural features that distinguish them from Arab or Chinese communities. Arabs, Chinese and Westerners, however, are not part of any broader cultural identity [8].

In his work on 'Orientalism', Edward Said, a critic of Huntington, critically examines how the West has reimagined, reconstructed and culturally reframed 'the Orient' as a means of pacification, domestication, subjugation and domination [9]. The orientalization of others has been a feature of European perception and representation of colonial and post-colonial societies [10]. This is part of a broader narrative of racial hierarchy which ranks 'other' societies as inferior and the West as the indisputable force for human civilization and progress [11]. The 'civilizing mission' became a part of European capitalist imperialism via its many constituent agencies such as Christianity, liberalism, racial superiority, science and military intervention [12].

This broad theme of image making to frame and define others is the central focus of this paper. It focuses primarily on the historical roots of Sinophobia, the racialized construction of Chinese threat. The perception of an aggressive Chinese state, potentially hegemonic Chinese culture and expansionist economic interests through the Belt and Road initiative have all contributed to the construction of an imagery which is both racialized and a leverage for geopolitical and strategic contestation. Racialized framing works both ways. Chinese nationalism and anti-foreigner perception have been documented and goes back into history [13, 14]. While a lot have been written about Sinophobia, this chapter is more concerned with its history and how it has evolved over the years to better understand some of the implicit racialized underpinnings of contemporary geopolitics, especially the growing anti-China narratives amongst the Western powers such as the USA and Australia.

A dominant feature of contemporary Pacific geopolitics is the way China is demonized by the 'Western' powers such as Australia, the USA, France and New Zealand as illegitimate intruders into a part of the world which Australian prime minister, Scott Morison, referred to as 'our own backyard' [15]. Referring to a move it attempted to sponsor to investigate the origin of COVID-19, the 
Australian prime minister insinuated that the 'West' should show solidarity and decisiveness against China's 'imperial power' and 'bully' tactics [16].

Sinophobic narrative has morphed into an everyday political cliché as a result of repetitive enunciation over time, its role in geopolitical and ideological leveraging runs deep into the realm of cultural and racial prejudice to the extent that geopolitical paranoia has 'blended neatly with thoroughly racialized forms of Western knowledge production' [17]. The Sinophobic narratives and manoeuvrings by the USA, France and Australia in the Pacific today have deeper racial and historical roots which can be traced back to the Western powers' fear and demonization of China in the nineteenth century when global colonial interests began in earnest as well as the international transportation and treatment of Chinese labourers and how these shaped racial perceptions [18]. Sinophobia was a convenient ideological tool to justify capitalist penetration of China and the transportation and exploitation of cheap Chinese labour to other parts of the world. Today, Sinophobic sentiments form a justificatory geopolitical narrative for Western powers and this is certainly the case in the Pacific region, which has been an arena of big power contestation for much of the twentieth century.

The colonial history of anti-Chinese geopolitical narratives has evolved over the years and strands of this racialized perception continue today in both explicit and implicit forms since the European imperial penetration of China during the eighteenth and nineteenth centuries. These racialized imageries were used to justify extraction of Chinese labour, resources, land and control of its market. Colonial expansion and capitalist penetration were symbiotic processes [12]. This was a similar story throughout the world where European colonialism needed to justify their economic and political conquest by framing the colonized as readily exploitable subhumans with lower levels of intelligence and culture [19]. This trend continues and is part of global geopolitics where subconscious cultural and racialized bias underpins security and developmental narratives [20]. Western perceptions of non-Western states are often coloured with a sense of 'otherness', difference and even superiority-inferiority relationship. In the Pacific, this was characteristic of Western perception of the Soviet Union during the Cold War and of China in the post-Cold War era. Overall, this paper makes the assertion that the Sinophobic narratives which help to define Pacific geopolitics in the contemporary era have deeper historical roots which are linked to the racialization of imperial conquest and exploitation in the last three centuries.

This paper examines the historical genesis and early manifestations of Sinophobia and the extent to which it has been fused into contemporary geopolitical discourse of contestation. It firstly examines the role and significance of some of the recent Sinophobic narratives in the context of Pacific geopolitics; and secondly, the paper provides a discussion of some historical moments which spawned Sinophobic paranoia. The focus will be on four cases of Sino-Western encounters: the British colonial penetration of China and how these have shaped Sino-British political and cultural relations; Chinese labour transportation to and exploitation in the USA; the French yellow peril paranoia and how that shaped the country's colonial perceptions and policies and the evolution and manifestations 
of Australian anti-Chinese racism and how this has influenced contemporary Sinophobic geopolitical position in the region.

\section{Pacific Geopolitics: the China Versus the West Encounter}

The rising Sinophobic narrative in global geopolitics has to be seen in the broader context of power contestation where the West has been trying to defend its traditional areas of control which resulted from colonial and post-colonial expansionism and pacification and on the other hand, China's attempt to make inroads into these countries. China seeks to challenge Western dominance by imitating the West's economic expansionist tendencies through 'checkbook diplomacy', technological penetration, political manoeuvering and digital surveillance [21]. In recent years, under Xi Jinping, as the competition escalates economically and politically, China's approach has increasingly become more strategic and assertive through the use of military, academic and other civilian connections [22]. The dramatic unfolding of China's Belt and Road initiative through expansion of diplomatic and economic empire into parts of the world, which have been part of the West's spheres of influence in the Global South (especially in the Asia-Pacific region, Africa and Indian Ocean), has invoked perceptions of Chinese economic and cultural takeover of the world. The issue here is not only an economic one, as often assumed, as there is a deeper historical and ethno-cultural consciousness that the Chinese are 'different' and that their values are not only incompatible with those of the West, they also pose a threat.

The continuing crackdown on democratic rights in Hong Kong, the human rights abuses of the Uighur minorities and the initial suppression of news about COVID19 in Wuhan Province have all added more fuel to the existing Sinophobic soundbites and played well into the West's strategic narrative. These narratives provided the ideological justification for the trade wars (under President Donald Trump) [23], formation of the Indo-Pacific axis to counter Chinese expansion in the Asia-Pacific region [24], increase in the arms trade and militarization of the Asia-Pacific region, securitization of high tech digital systems such as 5G and anti-China surveillance systems by the Five Eyes [25]. The solidarity amongst the Five Eyes alliance has been loosened as a result of New Zealand's pursuance of a more independent foreign policy towards China. China has responded in kind to the sanctions against it and both sides find themselves in a battle for power, knowledge, control and narrative, while ironically, maintaining strong economic links through trade. The COVID-19 pandemic has intensified the tension, as China was consistently targeted, especially by Trump, as the cause of the global misery and thus must be investigated. 'The world is now suffering as a result of the misfeasance of the Chinese government', Trump suggested, as he blamed China for the pandemic and threatened to withdraw from the World Health Organization for being 'China-centric' [26].

The battle of narratives and the competition for 'soft power' influence are manifested more directly through aid, and Pacific Island Countries (PIC) have been at the centre of this 'checkbook diplomacy' [27]. Within the last two decades, narratives about a possible Chinese domination of the Pacific have become normal discursive 
clichés which feature frequently in the media. Criticism of Chinese aid, allegations of a possible Chinese naval base in Fiji and later Vanuatu, warnings of increased China-induced debt and eventual take-over if loans are not paid, Chinese manipulation and corruption of local governance, infiltration of local politics and society by Chinese agents, to name a few of seemingly endless allegations, have been pushed continuously by politicians, media and scholars. There is no doubt that some of these allegations such as increased debt are based on real life experience while at the same time there are also indications that some are based on Cold War-type hysteria.

One of the political fallouts of the COVID-19 pandemic is the way in which it has invoked and exacerbated existing Sinophobic prejudices [28]. Former US President Donald Trump, for instance, took advantage of the situation to call the COVID19 a 'Chinese virus' and threatened to launch an international legal case to sue the Chinese Communist Party (CCP) for causing the global misery [29]. In response to accusations of racism, Trump retorted that:

It's not racist at all. No, it's not at all. It's from China. That's why. It comes from China. I want to be accurate [30].

Joe Biden's election as the new President of the USA has not substantially changed the approach to China nor has it subdued anti-Chinese feelings in the USA. If anything, there has been a recent spike in anti-Asian violence and since March 16, 2021, there had been a 150\% rise in anti-Chinese hate crime [31] (Murphy, 2021). At the national policy level, President Biden's Interim National Security Strategic Guidance prioritizes 'Chinese aggression' as constituting 'threats to our collective security, prosperity, and democratic way of life' [32].

The Sinophobic narratives in the Pacific have intensified over the years, especially in a post-truth world where fake news and digital lies are part of daily narratives of power and control. The initiatives to counter Chinese influence in the Pacific, trade wars between China and the USA, the vilification of China as the source of COVID19 and fear of Chinese economic hegemony have provided the backdrop to the continuing tension and power dynamics. Central to these are two important interrelated variables - the politics of identity and the politics of the market. Pacific Island Countries (PICs) are constantly being cautioned by the USA and Australia about Chinese predatory and exploitative intents [33] (Barrett, 2020). Unless of course, the knights in shining armour, the touch bearers of Anglo-Saxon 'civilization', intervene to save the helpless islanders from eternal damnation. This narrative is not new-it's reminiscent of the old nineteenth century yellow peril fear mongering. The solution back then and indeed now is simple. The Anglo-Saxon supermen will swoop down from out of the clouds to save the islanders and the world from the imminent threat.

What are some strategic issues at stake here? For the USA, China poses a direct threat to its global hegemonic ambitions to project its strategic and economic interests. China is seen as both a direct competitor and a spoiler and under Donald Trump, this reached new levels of racial and ideological posturing. The USA sees the Asia-Pacific as a huge and constantly expanding market, source of raw materials and part of its alliance and sphere of influence [34]. Chinese economic expansion and political influence in the region have created conditions for direct confrontation between the two hegemons. Since the end of World 
War II, the Pacific had become a sort of American Lake, with military bases and surveillance systems located all around the rim and islands in the Pacific [35]. Under the doctrine of 'strategic denial', the USA delegated the role of caretaker to Australia and New Zealand to ensure that the Pacific was free of Soviet influence [27]. After the demise of the Soviet Union and the end of the Cold War, China emerged as the new threat and the USA had to shift the narrative to suit the new conditions. Australia was designated as a kind of 'Deputy Sherriff' to police the Pacific on behalf of the USA [36]. Australia played this role loyally, knowing that it will also serve its own strategic interests, which are closely tied to those of the USA.

Australia basically sings the same Sinophobic tune as the USA and in recent months, there has been a similar surge in anti-Chinese and anti-Asian sentiments in Australia [37]. To Australia, the Pacific is considered its natural backyard in which it has the right to engage and 'protect' at all cost. The anti-Chinese sound bites regarding the Pacific emanating from Canberra is almost a repetition of those coming out of Washington. The tone can be patronizing to the extent that Pacific Island Countries are insulted. For instance, when in January 2018 former Australia's Minister of International Development Concetta Fierravanti-Wells stated that Beijing was constructing 'useless buildings' and roads to 'nowhere' in Pacific Island states, there was a chorus of protests by Pacific leaders who felt insulted by the Australian minister's insinuation [38]. Australian allegations of Vanuatu conspiring with China to build a naval base in the country were vehemently rejected by Vanuatu and the theory was found to be speculative [39]. This Sinophobic gesture by Australia is not new because it simply sits on a deeper history of racism expressed through its White Australian policy of the 1900 s.

The rising chorus of the anti-Chinese narratives provides a great opportunity for France to reassert its colonial hegemony in Oceania. Already it has manoeuvred its way into the Pacific Island Forum via New Caledonia and Tahiti, its two major Pacific territories (through the support of Australia and New Zealand). President Emmanuel Macron's visit to New Caledonia in early May 2018 was timed perfectly to coincide with the campaigns leading up to the independence referendum in New Caledonia. It was also an opportunity for him to visit Australia (to negotiate aircraft sales) where he told journalists that, in response to Chinese threat, France's expansion in the region was to ensure 'rules based development' and to 'preserve necessary balances' and 'not to have any hegemony in the region' [40].

The Sinophobic discourse serves a number of strategic purposes. In the broader geopolitical sphere, it is a way of the USA using it as a means of nullifying the legitimacy of Chinese presence and expansion as a global power. At the level of regional hegemony, for regional powers like Australia, it is a way of mobilizing the loyalty of small island states in the Pacific away from Chinese influence. To consolidate this geopolitical mobilization further, the battle has a more implicit emphasis as a way in which Western powers project a racialized imagery of European culture as being superior. 


\section{The Race for Chinese Market and Labour: British and American Interests}

For a long time, since the second century BCE until the eighteenth century, during the period of the Silk Road trade between Europe and the East, the West had a mythical fascination with China, a period of Sinophilia (interest in China), one might say. When early missionaries and mercantile traders established themselves from the sixteenth century onwards, relationships were generally cordial but racialized perceptions began to take root and this intensified in the nineteenth century during the period of colonialism. Western imperialism demanded more aggressive global competition over resources and markets and this led to a violent encounter with China in the form of the Opium Wars [41]. In this transition from Sinophilia to Sinophobia, Zhang argues that, 'In the case of Sinophilia and Sinophobia, the encounter between Europe and China prior to 1800 is marked less by China's effort to gain Europe's recognition than by Europe's reaction to the challenge posed by Chinese thought' [42].

Britain's attempt to 'open up' the Chinese market through the illegal opium trade triggered the two Opium Wars, the first from 1839 to 1842 and the second from 1856 to 1860 , both driven by the economic imperative of global capitalist expansion, underpinned by the cultural dogma of European superiority over the 'uncivilized' Chinese [41]. The Chinese were defeated on both occasions and this in some ways vindicated the racialized assumptions of the Western destiny. One of the consequences of this was the Treaty of Nanking in 1842 which gave Britain control over Hong Kong. Meanwhile, the French also signed the Treaty of Huangpu in 1844 and the Americans the Treaty of Wangxia also in 1844 as Western powers attempted to set up trading posts and access the Chinese market. This was a period of humiliation for China and responses against European incursions were met with even harsher acts of vengeance. The French and the British even signed a treaty in 1857 to attack and occupy Guangzhou (Canton).

Not only were the Western powers eager to penetrate the Chinese market, they were also interested in exploiting its huge reserve of labour. The expansion of global capitalism and its demand for cheap labour led to the notorious slave trade which saw millions of Africans being shipped off to the Americas and later after the 'gradual abolition' of slavery, labourers were transported from Asia, Pacific and other parts of the world to work on colonial plantations, railway lines or mines [43]. During the nineteenth century, a large number of Chinese were 'recruited' as labourers and 'coolies' (term used to refer to Asian labourers) were exploited for the purpose of extracting maximum labour to serve the interests of global capital [44].

In 1806, after the end of the slave trade, the British experimented with the new labour arrangement by importing 200 Chinese to Trinidad [45]. Unlike Indian labourers who were mostly transported to British colonies in the Caribbean, Africa, Asia, Pacific and Indian Ocean, Chinese labourers were exported to other European colonies. Between 1847 and 1874, around 250,000 to 500,000 Chinese labourers were imported to various British, French, Dutch and Spanish 
colonies in the Americas, Africa and Southeast Asia. This included 125,000 who were sent to Cuba [46]. The harsh treatment of Asian labourers, who had to work in slave-like conditions, created international controversy and in 1855, the British withdrew its ships carrying labourers to Cuba and Peru and in 1862, the USA, through a law issued by President Lincoln, banned the coolie trade [47]. The Portuguese also ended the coolie trade in 1874 as a result of international pressure. The dehumanization of racialized labour by colonial capitalism reinforced the view about the natural inferiority of non-Whites, including the Chinese.

While the anti-Chinese feelings were prevalent in all European societies, the actual policies of the states differ. In the USA, this was institutionalized in two ways. Firstly through the racialized economic division of labour which relegated Chinese labourers together with blacks and other non-whites, to the lowest rung of the production structure and secondly the use of immigration laws to control Chinese entry into the country. The Chinese labourers arrived in the early 1840s during the California gold rush and many were also involved in building the First Transcontinental Railroad where they were largely treated as dispensable subhuman [48]. Their worth was measured in terms of the amount of labour they provided, not in terms of their values as a human group. Thus anti-Chinese racism was very much part of their daily life and this was amplified by the various anti-Chinese policies and laws of the government. China was aware of the situation and was keen to remedy it. With this in mind as well as in response to the US's demand for more labour, China signed the Burlingame Treaty with the USA in 1868 to ensure that Chinese labourers can enter and leave the USA freely as well as enjoy residential rights. The treaty also accorded the 'most-favoured' status for Chinese nationals; however, it still forbade naturalization of the Chinese to become citizens [49]. While this stimulated immigration, it also created a racial backlash as Chinese were vilified and used as scapegoats by politicians running for elections. Anti-Chinese referendums were initiated in California and Nevada and politicians campaigned to put a stop to Chinese immigration once and for all, leading to the Chinese Exclusion Act. The Burlingame Treaty was later modified by the Angell Treaty of 1880, which restricted Chinese immigration.

Prejudice against Chinese migrant workers was prevalent especially by those in lower socio-economic strata because the Chinese were scapegoated for low wage levels by politicians and labour leaders. There were cases of anti-Chinese violence leading to murder. Criminal activities including murder were blamed on the Chinese in general and this led to the harassment of Chinese across the country. Trade unions saw Chinese workers as a threat to white workers' welfare and this spread animosities amongst the American working class [48]. Parallels could be drawn here with the recent spate of anti-Asian violence in the USA buoyed up by Trump's anti-China rhetoric and rise in anti-immigrant right-wing racism [50].

A number of exclusionary and discriminatory measures were taken against the Chinese community in the 1870s and 1880s [51]. For instance, the State of California illegalized the employment of Chinese by state and local government as well as by businesses incorporated in California in its 1879 Constitution. The constitution also gave powers to the Californian local governments to expel people of Chinese extraction from within their areas of jurisdiction. In 1882, the Chinese Exclusion Act was passed to restrict immigration from China but this was repealed by the 
Chinese Exclusion Repeal Act of 1943, when China became a US ally during World War 11. Despite this, Chinese were still not allowed to own property and there were still some restrictions in immigration quota [52].

The Naturalization Act of 1870 extended citizen rights to African Americans but still barred the Chinese and other Asians from naturalization based on the perception that they lacked the capacity to be assimilated into the dominant white culture. This rendered them aliens who could not become citizens, thus could not vote nor serve on juries. The argument of primordial racial difference and inassimilable cultural norms dominated the exclusionary narrative. For instance, Supreme Court Justice John Marshal, in landmark judgment to uphold racial segregation in the Plessy vs Ferguson (1896) case, wrote of the Chinese:

... a race so different from our own that we do not permit those belonging to it to become citizens of the United States. Persons belonging to it are, with few exceptions, absolutely excluded from our country. I allude to the Chinese race [53].

Growing Sinophobia led to the enactment of the Page Act of 1875 to curtail immigration of Chinese women. It responded to 'what were believed to be serious threats to white values, lives, and futures' [54]. This was followed by the Chinese Exclusion Act of 1882 to stop further Chinese labour migration and naturalization. The act was largely influenced by American merchants, missionaries and diplomats who provided very negative reports about the Chinese people and their culture and these triggered the 'yellow peril' narrative and fear which continued through the cold war and during McCarthyism and continues today. A decade later, the Geary Act (1892) was passed to extend the Chinese Exclusionary Act by requiring Chinese to carry a resident permit. Some of these racialized perceptions and feelings linger in different shades and manifestations to this very day.

The Immigration Act of 1917 added more restrictions to Chinese immigration by creating an 'Asian Barred Zone' through the use of literacy test for immigration [55]. Further restrictions were provided by the 1921 Emergency Quota Act and the 1924 Immigration Act, both inspired by the xenophobic fears in the White AngloSaxon Protestant (WASP) community of being swamped by alien 'undesirables'. The National Origins Formula which came to being in 1929 attempted to ally this fear by ensuring that a quota system proportional to the actual population will help preserve the 'national character' of the country [56]. This was repealed in the Immigration and Nationality Act of 1965 [57]. Again the prevalence of these anti-immigrant policies persists in various forms in the USA today [58].

Xenophobia provided ideological fodder for the US newspapers which started popularizing the 'yellow peril' narrative by the turn of the twentieth century. In 1911, an influential religious personality, G. G. Rupert published the popular The Yellow Peril; or, Orient vs. Occident which was derived from the phrase 'the kings from the East' in the biblical text Revelation 16:12. With a Christian evangelical prism, Rupert believed that Jesus was going to intervene to save the Britain and USA from being attacked by Asians [59]. In the 1930s, pulp magazines contained a lot of yellow peril characters that resembled Fu Manchu, a stereotypic evil character created by British author Sax Rohm [60]. A series of Fu Manchu films were made to caricature the Chinese 'evil' personality and this fuelled into the already steaming yellow peril racial mythology [61]. 
The Russo-Japanese War shifted the yellow peril xenophobia from the Chinese to the Japanese and during the Second World War, China was on the side of the allies. The USA-China relationship was quite complex during the Cold War where the USA took advantage of the China-Soviet tension to strengthen ties with China. This all changed after the Cold War when, as a result of increasing prospects of Chinese hegemony, the West reverted back to the prejudices of the past to bolster their strategic interests of the present. Thus, although a lot have changed in the USA in terms of ethnic relations and international engagement, the yellow peril threat, which has its roots in the $1800 \mathrm{~s}$, still shimmers in the country's sub-consciousness and this is readily invoked when its global interests are deemed threatened. The anti-Chinese sentiments and narratives mentioned earlier are manifestations of how the ghosts of the past continue to haunt contemporary ethnic relations. While the terminologies may have slightly changed, the deeper racialized consciousness still connects the past to the present in a powerful way.

\section{The French and peril jaunte}

The peril jaunte (yellow peril) narrative in France was also linked to colonial interests in China. French engagement with China started with the Jesuits in the seventeenth and eighteenth centuries and later French researchers sent by Louis XIV to the Kanxi Emperor had a notable influence on Chinese sciences. In turn, Chinese culture and style became fashionable in France and the country became a vibrant centre for Chinese porcelains, silks and lacquers and European imitations of these goods. The first known visit to France of any Chinese was in 1684 and this was followed by others in later years. French relationship with the Chinese took a more cultural and intellectual form in the seventeenth and eighteenth centuries, but this changed dramatically during the colonization period of the nineteenth century as the rush for markets and resources started [62].

France and China signed the Treaty of Huangpu in 1844 which ensured that the French were accorded the same privileges and rights as the British. Tension culminated in the ransacking of the Summer Palace in 1860 by Anglo-French units which led to mass looting and transportation of precious objects to French museums. France also seized Guangzhouwan as a treaty port and the city was leased to France for 99 years. Conflict came to a head during the war over Indochina (now Vietnam) in 1884 to 1885 , which France won and enabled it to lay claim on Vietnam. France was also part of the eight-nation alliance which put down the boxer rebellion in 1900 [63].

These events shaped the perception of the Chinese as representing a fiercely antiWestern culture. French consciousness also caught on to the anti-Chinese sentiments in the European imagination at the time. The war and tension between China and France, the urge to legitimize colonial expansionism and the increase in the number of Chinese labourers entering the Western capitalist market saw a surge in Sinophobia in France. By the 1890s, the threat of péril jaune had taken root, driven by the fear of being outnumbered by the Chinese. On the basis of this, the French press publicly supported Russia during the Russo-Japanese war (1904-1905) because 
the Russians were considered heroic defenders of the white race against the yellow peril. French journalist René Pinon wrote in 1904 that: 'The yellow peril has entered already into the imagination of the people.... In a setting of conflagration and carnage, Japanese and Chinese hordes spread out over all Europe, crushing under their feet the ruins of our capital cities and destroying our civilizations, grown anaemic due to the enjoyment of luxuries, and corrupted by the vanity of spirit' [64].

Vietnam, a former French colony, was a living laboratory for France's antiyellow peril colonial obsession. French orientalism defined the Vietnamese firstly as sub-humans and secondly as ideological barbarians under the spell of Chinese communists who were conspiring to take over the world. In defending their La mission civilisatrice (the civilizing mission), during the Indo-China war (1946-1954), the French saw themselves as defenders of the white West against the threatening péril jaune. This was used to justify the atrocities against the Viet Minh prisoners of war during the la sale guerre, the dirty war against communism. The French media whipped up the yellow peril narrative by casting the Viet Minh as part of the many 'roaring waves' of 'fanatical' and 'innumerable yellow hordes' [59]. However, at the same time, at the political level, France was playing a tactical political game against the Soviets by becoming the first European power to recognize China as the sole representative of the Chinese people in 1964 [65].

In his book, Behind the bamboo hedge: The impact of homeland politics in the Parisian Vietnamese community (1991), Gisèle Luce Bousquet argued that the yellow peril stereotype continues to be a feature of contemporary French racial prejudice [66]. One of the most recent controversies was a cartoon on the front cover of the January 2015 issue of Fluide Glacial magazine titled, 'Yellow peril: Is it already too late?' It depicted Paris as a city under the control of Chinese invaders and showed a miserable looking French servant pulling a rickshaw with a Chinese passenger in the company of a scantly dressed French blonde [67, 68]. A similar situation recently caused controversy when the Le Courrier Picard, a French daily published a headline, 'Yellow alert' ('Alerte jaune') featuring a photo of an Asianlooking female wearing a mask [69].

\section{Australia and the 'Yellow Peril'}

The Australian version of Sinophobia is part of the Anglo-Saxon and European association of Chinese culture to atavistic sexuality, unrefined behaviour and threat to Western civilization by the yellow peril. It was based on the assumption that white races were superior and part of their eternal, God-given mission was to implant their unquestionable right over planet earth. The Aborigines, whom whites first encountered when they arrived in the content, were declared sub-humans and did not deserve to be treated as equal members of society and subsequently, their land was declared 'terra nullius' (nobody's land) to justify land theft. In the late 1800s as the Asian population grew, Australian literature and media were dominated by stories of invasion by the yellow peril. Amongst these was the novel White or Yellow?: A Story of the Race War of A.D. 1908 (1887), by William Lane, a journalist and labour leader, who depicted an innocent 
white Australian society being overrun by hordes of Asians who monopolized the industries and inflicted terror on Australians [70].

Under the Immigration Restriction Act of 1901, the infamous White Australia policies were adopted and sought to exclude Asians and Pacific Islanders. The then Australian Prime Minister, Edmund Barton, in support of the White Australian policy read a passage from Charle's Pearson's National life and character: A Forecast:

The day will come, and perhaps is not far distant, when the European observer will look round to see the globe circled with a continuous zone of the black and yellow races, no longer too weak for aggression or under tutelage, but independent, or practically so, in government, monopolising the trade of their own regions, and circumscribing the industry of the Europeans; when Chinamen and the natives of Hindustan, the states of Central and South America ... are represented by fleets in the European seas, invited to international conferences and welcomed as allies in quarrels of the civilised world. The citizens of these countries will then be taken up into the social relations of the white races, will throng the English turf or the salons of Paris, and will be admitted to inter-marriage. It is idle to say that if all this should come to pass our pride of place will not be humiliated... [71].

Also in 1901, the Australian parliament passed the Pacific Island Labourers Act of 1901 which legalized the deportation of Pacific island labourers in Australia as well as prohibited Pacific Islanders immigration into the country after 1904. This racial paranoia was projected internationally so during the Paris Peace Conference in 1919, Australia vehemently opposed Japan's recommendation for the adoption of a racial equality clause to be added to Article 21 of the Covenant of the League of Nations. Although the White Australia policy had been progressively disbanded over the years and Australia has increasingly become multicultural, the Anglo-centric cultural view is still dominant. Australia's 'natural' allies are other Anglo-Saxon countries which also members of the 'Five Eyes' global surveillance group (New Zealand, Canada, USA and Britain) and by virtue of its Euro identity, France is indeed welcome. The Chinese are seen as outsiders to this cultural circle as well as an ideological and economic threat to western hegemony. However, recently, New Zealand has opted to take a more independent approach to China instead of following the Five Eyes stance and this has caused a bit of discomfort in its relationship with Australia [72].

For the Pacific Island States, the tension between the West and China has created an environment of anxiety and instability but at the same time, it presents an opportunity to leverage the tension to serve their economic and political interests. One way of doing this is to 'support' both sides and play one against the other when the circumstances arise [27].

\section{Conclusion}

The wave of Sinophobia with roots in the nineteenth century colonial period became an institutionalized narrative in global politics. The violent encounters with the European powers, trying to extend the tentacles of capitalism into an imperial 
Chinese society rooted in an ancient civilization, shaped East-West relationship in a significant way. The combination of racial, ideological, economic and political factors created a prejudicially fertile environment to cast China as the perfect boogeymen, scapegoat and evil other. Because of its economic and technological power, China has been able to push back thus creating a major war of psychological attrition. The spectre of the yellow peril is still very much alive in different forms.

The racialized framing of others has been common throughout history and the West in particular has often seen itself to be superior in relation to other racial and cultural groups since the era of Enlightenment and even earlier. This Eurocentricperception of differences has continued over the years and as the paper has shown, it famed and legitimized colonial conquest, resources extraction, subjugation of nonEuropean races and even led to wars. China became a victim of this.

The yellow peril paranoia of the nineteenth century has taken a new level of articulation in this age of digital communication and global contestation for power. The USA, Australia and France have been at the forefront of the Sinophobic posturing in the Pacific because of their strategic, political and economic interests in the region. What this paper is interested in is the assertion that the Sinophobic narratives by the three powers have deeper historical roots which are linked to the colonial period when the Europeans used race as a tool to justify their superiority and the natural inferiority of the colonized non-white races. It was a lethal mix of predatory economic interests, imperial cultural domination, political hegemony and European racism. The social Darwinian doctrine of the natural superiority of European races was the major ideological fulcrum of colonial pacification which gave legitimacy to the subjugation, murder and looting of those they encountered in the process of global expansion.

All three powers are part of the Indo-Pacific axis to contain Chinese imperial ambitions in the form of the Belt and Road initiative. The Pacific has become a battleground for big power rivalry in a way which undermines the sovereignty of the PICs, in whose name, Sinophobia is often being articulated. Australia's 'step-up' and New Zealand's 'reset' policies are meant to keep the Chinese at bay but for many PICs, Chinese aid, despite its shortcomings, is critical for their development. The USA provides minimal aid while Australian and New Zealand aid, despite the high profile publicity has not really transformed, in any substantive way, the wellbeing of Pacific peoples and resilience of their economies. The political and ideological nature of aid to counter Chinese incursions undermines any attempts to make aid genuinely sustainable. However, the global expansionist policy of the Chinese Community Party through the Belt and Road initiative has simply reinforced the antiChinese stereotypes and plays into the West's Sinophobic narrative.

\section{References}

1. Bourne J. (2019). Unravelling the concept of unconscious bias. Race and Class, 60(4): 70-75. https://doi.org/10.1177/0306396819828608.; 71

2. Spoonley P. (2019). Racism and Stereotypes. In: Ratuva S. (eds) The Palgrave Handbook of Ethnicity. Singapore: Palgrave Macmillan. https://doi.org/10.1007/978-981-13-2898-5_36. 
3. Kinder D. R. (2013). Prejudice and Politics. In The Oxford Handbook of Political Psychology. 2d ed. Edited by Leonie Huddy, David O. Sears, and Jack S. Levy. Oxford: Oxford University Press: 812-851.

4. Kramer M. (1999). Ideology and the Cold War. Review of International Studies, 25(4): 539-576. Retrieved Jan 8, 2021, from http://www.jstor.org/stable/20097622.

5. Ali T. (2003). The clash of fundamentalisms: Crusades, jihads and modernity. London: Verso.

6. Dennis R. (1995). Social Darwinism, Scientific Racism, and the Metaphysics of Race. The Journal of Negro Education, 64(3), 243-252. https://doi.org/10.2307/2967206.

7. Huntington S. (1996). Clash of civilizations and the remaking of world order. New York: Simon \& Schuster.

8. Huntington S. (1993). The Clash of Civilizations? Foreign Affairs, 72(3): 22-49. https://doi.org/ $10.2307 / 20045621$

9. Said E. (1978). Orientalism. New York: Pantheon Books.

10. Zhang P. (2002). Orientalism: Western Conceptions of the Orient - On Edwad W. Said's Orientalism. Comparative Literature: East \& West, 4:1: 176-183. https://doi.org/10.1080/25723618. 2002.12015317.

11. Hall S. (1996). The west-and-the-rest: Discourse and power in modernity. Cambridge (MA): Blackwell Publishers.

12. Williams E. (1994). Capitalism and slavery. Chapel Hill: The University of North Carolina Press.

13. Pai H-H. (2020). The coronavirus crisis has exposed China's long history of racism. The Guardian. https://www.theguardian.com/commentisfree/2020/apr/25/coronavirus-exposed-china-histo ry-racism-africans-guangzhou. Accessed 12 Feb 2021

14. Weatherlet R. (2018). Defending the nation: The role of nationalism in Chinse thinking on human rights. Democratization, 15(2): 342-362. https://doi.org/10.1080/13510340701846418

15. Rounds Sally. (2019). Australian PM heads out to Pacific "backyard." https://www.scoop.co. nz/stories/HL1901/S00045/australian-pm-heads-out-to-pacific-backyard.htm. Accessed 30 Aug 2020

16. Zimonjic P. \& Kapelos, V. (2020). Canada, Australia have to stand up to 'bullies' like China, says former Australian PM. https://www.cbc.ca/news/politics/turnbull-china-covid-trudeaubook-1.5587328. Accessed 12 Jan 2021

17. Bell D. (2013). Race and international relations: introduction. Cambridge Review of International Affairs, 26(1): 1-4, https://doi.org/10.1080/09557571.2013.77029.

18. Lyman S.M. (2000). The "yellow peril" mystique: Origins and vicissitudes of a racist discourse. International Journal of Politics, Culture, and Society, 13:683-747. https://doi.org/10.1023/A: 1022931309651.

19. Shain F. (2020). Race matters: confronting the legacy of empire and colonialism, British Journal of Sociology of Education, 41:2: 272-280. https://doi.org/10.1080/01425692.2020.1717104

20. Pan C. (2021). Racialised Politics of (In)Security and the COVID-19 Westfailure. Critical Studies on Security, https://doi.org/10.1080/21624887.2021.1904195.

21. Lee K-F. (2018). AI Superpowers: China, Silicon Valley, and the new world order. Boston, Mass: Houghton Mifflin.

22. Brady A-M. \& Pheloung S. (2020). China's exploitation of civilian channels for military purposes in New Zealand. https://www.wilsoncenter.org/sites/default/files/media/uploads/docum ents/2020-07-HoldingAPenInOneHand-Brady.pdf. Accessed 12 Feb 2021

23. Ahmed A. (2021). Stoked by Trump, paranoia about China is fuelling anti-Asia racism. Huffpost. https://www.huffpost.com/entry/china-racism-foreign-policy_n_60526913c5b6264a8fb8ff37.

24. de Swielande T.S. (2014). The Indo-Pacific: The New Great Game between China and the United States. In: Dessein B. (eds) Interpreting China as a regional and global power. Politics and Development of Contemporary China Series. London: Palgrave Macmillan. https://doi.org/10. 1057/9781137450302_10.

25. Gardner F. (2021). Five eyes: Is the alliance in trouble over China? BBC News. https://www.bbc. com/news/world-56970640. Accessed 21 Feb 2021

26. Shaw A. (2020). Trump announces US 'terminating' relationship with WHO. https://www.msn. com/en-nz/news/world/trump-announces-us-terminating-relationship-with-who/ar-BB14M79c? ocid=spartanntp. Accessed 3 Jan 2021

27. Ratuva S. (2014). A new cold war? American and Chinese posturing in the Pacific." Asia-Pacific Policy Review (ANU), 1 (2): 409-422. https://onlinelibrary.wiley.com/doi/full/10.1002/app5.38. 
28. Chowdhury A \& Sundaram J. (2020). 'Passing the buck' becomes reckless 'conspiracy blame game'. Inter Press Service New Agency. http://www.ipsnews.net/2020/05/passing-buck-becomesreckless-conspiracy-blame-game/. Accessed 10 Feb 2021

29. Viala-Gaudefroy J. \& Lindaman D. (2020) (April 22). Donald Trump's 'Chinese virus': the politics of naming. https://theconversation.com/donald-trumps-chinese-virus-the-politics-of-naming136796. Accessed 5 Jan 2021

30. Forgey Q. (2020). Trump on 'Chinese virus' label: 'It's not racist at all'. 18 March. https://www.polit ico.com/news/2020/03/18/trump-pandemic-drumbeat-coronavirus-135392. Accessed 5 Jan 2021

31. Murphy M. (2021). 'An existential threat': how anti-Chinese discourse in foreign policy lends itself to anti-Asian hate. The Brown Daily Herald, Sunday April 4. https://www.browndailyherald.com/ 2021/04/04/existential-threat-anti-chinese-discourse-foreign-policy-lends-anti-asian-hate/. Accessed 30 May 2021

32. Biden J. (2021). Interim National Security Strategic Guidance. Washington: White House. https:// www.whitehouse.gov/wp-content/uploads/2021/03/NSC-1v2.pdf. Accessed 12 Apr 2021

33. Barrett J. (2020). US warns pacific islands about Chinese bid for undersea cable project-source. https://www.reuters.com/world/asia-pacific/exclusive-us-warns-pacific-islands-about-chinese-bidundersea-cable-project-2020-12-17/. Accessed 13 Feb 2021

34. Schneider-Petsinger. (2021). Three pillars of a US trade strategy in Asia-Pacific. Chatham House. https://www.chathamhouse.org/2021/03/three-pillars-us-trade-strategy-asia-pacific. Accessed 15 Apr 2021

35. Firth S. (2013). New Developments in the International Relations of the Pacific. Journal of Pacific History, 48(3), 286-292. https://doi.org/10.1080/00223344.2013.812545.

36. Fickling D. (2004). Australia seen as "America's deputy sheriff.' The Guardian. https://www.thegu ardian.com/world/2004/sep/10/indonesia.australia. Accessed 20 Oct 2020

37. Zhou N. (2021). Death threats, distrust and racism: how anti-Chinese sentiment in Australia 'seeped into the mainstream.' Guardia, 4 March, 2021. https://www.theguardian.com/australia-news/2021/ mar/04/how-anti-chinese-sentiment-in-australia-seeped-into-the-mainstream. Accessed 5 May 2021

38. Graue C. (2018). Federal minister Concetta Fierravanti-Wells accuses China of funding 'roads that go to nowhere' in the Pacific. ABC News, 10 January 2018. https://www.abc.net.au/news/2018-0110/australia-hits-out-at-chinese-aid-to-pacific/9316732. Accessed 23 Jan 2021

39. O'Keefe M. (2018). Response to runours of a Chinese military base in Vanuatu speaks volumes about Australian foreign policy. The Conversation, April 12, 2018. https://theconversation.com/ response-to-rumours-of-a-chinese-military-base-in-vanuatu-speaks-volumes-about-australian-forei gn-policy-94813. Accessed 15 Feb 2021

40. France24. (2018). Macron visits French territory New Caledonia ahead of independence referendum. France24. https://www.france24.com/en/20180503-france-macron-visits-new-caledonia-indep endence-referendum-kanak-caldoche. Accessed 13 Feb 2021

41. Soothill W. (2009). China and the west. London: Westholme Publishing.

42. Zhang C. (2008). From Sinophilia to Sinophobia: China, history and recognition. Colloquia Germanica, 41(2): 97-110. https://www.jstor.org/stable/23981714?seq=1\#metadata_info_tab_contents. Accessed 13 Dec 2021

43. Emmer P.C. (1986). Colonialism and migration; Indentured labour before and after slavery. Amsterdam: Springer.

44. Christopher E., Cassandra P. \& Marcus B. R. (2007). Many middle passages: Forced migration and the making of the modern world. Berkeley: University of California Press.

45. Lai W. L. (1993). Indentured labor, Caribbean sugar: Chinese and Indian migrants to the British West Indies, 1838-1918. Baltimore: Johns Hopkins University Press.

46. Hu-DeHart E. (1993). Chinese coolie labour in Cuba in the nineteenth century: Free labour or neoslavery?" Slavery and Abolition, 14(1): 67-83.

47. Jung M-H. (2005). Outlawing "coolies": Race, nation, and empire in the age of emancipation. American Quarterly, 57(3): 677-701.

48. McClain C. J. (1994). In search of equality: the Chinese struggle against discrimination in 19thcentury America. Berkeley: University of California Press.

49. Schrecker J. (2010). For the equality of men - for the equality of nations: Anson Burlingame and China's First Embassy to the United States, 1868. Journal of American-East Asian Relations. 17 (1): 9-34. 
50. Tavernise S. \& Oppel R. (2020). Spit on, yelled at, attacked: Chinese-Americans fear for their safety. The New York Times, March 3, 2020. https://www.nytimes.com/2020/03/23/us/chinese-coronavirusracist-attacks.html. Accessed 14/3/2021

51. Rupert G.G. (1911). The yellow peril or the orient vs. the occident as viewed by modern statesmen and ancient prophets. Choctaw, Oklahoma: Union Publishing.

52. Kurashige L. (2016). Two faces of exclusion: The untold history of anti-Asian racism in the United States. Chapel Hill: University of North Carolina Press.

53. Justia. 1896. Plessy v. Ferguson - 163 U.S. 537 (1896): Justia US Supreme Court Center. Supreme. justia.com.

54. Luibhéid E. (2002). Entry denied: Controlling sexuality at the border. Minneapolis: University of Minnesota Press.

55. Bromberg H. (2015). Immigration Act of 1917. Washington: United States Government.

56. Chan S. (1991). "The exclusion of Chinese women, 1870-1943". In Chan, Sucheng (ed.). Entry Denied: Exclusion and the Chinese Community in America, 1882-1943. Philadelphia: Temple University Press.

57. Chin G \& Villazor R. C. (2015). The Immigration and Nationality Act of 1965: Legislating a new America. New York: Cambridge University Press.

58. Ministry of Foreign Affairs People's Republic of China. (2011). Official statement, Nov 15.

59. Shafer M. (2014). Deadly paradigms: The failure of U.S. counterinsurgency policy. Princeton: Princeton University Press.

60. Seshagiri U. (2006). Modernity's (yellow) perils: Dr. Fu-Manchu and English race paranoia. Cultural Critique, 62: 162-194. JSTOR 4489239.

61. Wu W. (1982). The yellow peril: Chinese Americans in American fiction, 1850-1940. Connecticut: Archon Book.

62. Harrison H. (2008). A penny for the little Chinese: The French Holy Childhood Association in China, 1843-1951. American Historical Review 113(1): 72-92. https://doi.org/10.1086/ahr.113.1. 72.

63. Eastman L. (1967). Throne and Mandarins: China's search for a policy during the Sino-French controversy, 1880-1885. Boston: Harvard University Press.

64. Tchen W, Kuo J \& Yeats D. (2024). Yellow peril! An archive of anti-Asian fear. London: Verso.

65. Wellons P. (1994). Sino-French relations: Historical alliance vs. economic reality. The Pacific Review, 7(3): 341-348. https://doi.org/10.1080/09512749408719102.

66. Bousquet G. L. (1991). Behind the bamboo hedge: The impact of homeland politics in the Parisian Vietnamese Community. Ann Arbor: University of Michigan.

67. Yan L. (2015). Provocative satire damages global appeal of France's cultural legacy. http://www. globaltimes.cn/content/903478.shtml. Accessed 12/12/2020

68. Atkinson D. (2015). The white Australia policy, the British empire, and the world. Department of History Faculty Publications. Paper 4. https://doi.org/10.3366/brw.2015.0191.

69. Boyle D. (2020). French Asians hit back at racism with 'I am not a virus' hashtag after newspaper runs 'Yellow Alert' coronavirus headline. https://www.dailymail.co.uk/news/article-7947865/ French-Asians-hit-racism-not-virus-hashtag.html. Accessed 20/3/2021

70. Affeldt S. (2020). 'White Sugar' against 'Yellow Peril' Consuming for national identity and racial purity. In Falcof, Nicky and Cashman-Brown, Oliver (ed). On whiteness. https://doi.org/10.1163/ 9781848881051_002.

71. Barton E. (2021). Quotation in House of Representatives, Commonwealth Parliamentary Debates, 7 August 1901. http://press-files.anu.edu.au/downloads/press/p97101/html/ch13s05.html\#ftn.d0e9524

72. Ensor J. (2021). Australia 'blindsided' by Nania Mahuta's Five Eyes comments as Andrew Bolt blasts 'woke mystic babble.' Newshub. https://www.newshub.co.nz/home/politics/2021/04/australiablindsided-by-nanaia-mahuta-s-five-eyes-comments-as-andrew-bolt-blasts-woke-mystic-babble. html. Accessed 5/5/2021

Publisher's Note Springer Nature remains neutral with regard to jurisdictional claims in published maps and institutional affiliations. 